\title{
Enzymatic and mRNA Transcript Response of Ovine 6-Phosphogluconate Dehydrogenase (6PGD) in Respect to Different Milk Yield
}

\author{
Stamatina Trivizaki, George P. Laliotis, Iosif Bizelis, Maria A. Charismiadou, \\ and Emmanuel Rogdakis
}

Department of Animal Science, Laboratory of Animal Breeding and Husbandry, Agricultural University of Athens, Iera Odos 75, 11855 Athens, Greece

Correspondence should be addressed to Iosif Bizelis, jmpiz@aua.gr

Received 21 June 2009; Accepted 1 September 2009

Academic Editor: Edna S. Kaneshiro

Copyright (C) 2010 Stamatina Trivizaki et al. This is an open access article distributed under the Creative Commons Attribution License, which permits unrestricted use, distribution, and reproduction in any medium, provided the original work is properly cited.

Ovine 6-phosphogluconate dehydrogenase (6PGD) is an enzyme of the pentose phosphate pathway, providing the necessary compounds of NADPH for the synthesis of fatty acids. Much of research has been conducted both on enzymatic level and on molecular level. However, to our knowledge, any correlation between enzymatic activity and 6PGD gene expression pattern related to different physiological stages has not been yet reported. With this report, we tried to highlight if any correlation between enzymatic activity and expression of ovine 6PGD gene exists, in respect to different milk yield. According to the determined enzymatic activities and adipocytes characteristics, ewes with low milk production possessed a greater $(P \leq .001) 6 \mathrm{PGD}$ activity and larger adipocytes than the highly productive ewes. Although 6PGD expression pattern was higher in low milk yield ewes than in ewes with high milk production, this difference was not found statistically significant. Thus, 6PGD gene expression pattern was not followed by so rapid and great/sizeable changes as it was observed for its respective enzymatic activity, suggesting that other mechanisms such as post translation regulation may be involved in the regulation of the respective gene.

\section{Introduction}

6-Phosphogluconate dehydrogenase (6PGD) is an oxidative carboxylase that catalyzes the decarboxylating reduction of 6phosphogluconate into ribulose 5-phosphate in the presence of NADP. This reaction is a component of the hexose monophosphate shunt and pentose phosphate pathways.

The functional importance of the enzyme is generally recognized in providing NADPH for fat synthesis and ribose for nucleic acid synthesis [1]. In farm animals, fat synthesis affects the economic return of the producer [2]. Excess fat deposits influence negatively meat quality, grading of carcasses, and in high milk yield animals, their health status and future performance.

Prokaryotic and eukaryotic 6PGDs are proteins of about 470 amino acids whose sequences are highly conserved. The amino sequences of almost 40 different 6PGDs have been reported including human [3], mouse [4], rat [5], and pig [6]. The protein is a homodimer in which the monomers act independently. Each contains a large, mainly alpha-helical, domain and a smaller beta-alpha-beta domain, containing a mixed parallel and antiparallel 6-stranded beta sheet. NADP is bound in a cleft in the small domain, the substrate binding in an adjacent pocket $[7,8]$.

In ruminants, extensive studies have been reported only for sheep and its cDNA. Carnet and Walker [9] were the first who determined the protein sequence of 6PGD reporting the isolation and characterization of 466 amino acids. However, this sequence information was incorrect due to misalignment of the peptides resulting during the protein determination. Somers et al. [10] revised the amino acid sequence based upon the isolation of the cDNA clones encoding the 6PGD 
gene in sheep. Thus, the isolated cDNA encodes a protein of 482 aa with a molecular mass of $52 \mathrm{kDa}$. The conservation of the protein sequence is very high as it shares an over $50 \%$ similarity with the protein encoded by the E. coli 6PGD gene and over $80 \%$ similarity with that of mammals (human, rodents, pig).

It is known that in dairy ruminants major changes occur during lactation in the metabolism of several tissues such as adipose tissue, as part of the homeorhetic control of the organism. In many cases, as the animals are unable to consume sufficient energy during lactation, utilizes body reserves. During the last decades a lot of research has been conducted on enzymatic level showing the reaction of 6PGD activity in respect to different stimuli $[2,11-16]$ without, however, involving any study on molecular level (i.e., mRNA transcripts). Herein, we report for the first time the effect of different ovine milk yield of Chios breed ewes on the characteristics of adipocytes, on enzymatic activity and expression of 6PGD gene.

\section{Materials and Methods}

2.1. Animal Treatment. The experiment was carried out in the Experimental Station of the Agricultural University of Athens. Twenty Chios breed ewes aged 2-4 years old and with an average $( \pm$ S.E) live weight of $55.4 \pm 1.8 \mathrm{~kg}$ were randomly selected and divided in two groups according to their milk production after the weaning ( $40 \pm 3$ days post partum). Group A and Group B included animals with high (each animal possessed $>1700 \mathrm{~kg} /$ day, $n=6$ ) and low milk production (each animal possessed $<1100 \mathrm{~kg} /$ day, $n=14$ ), respectively.

The ewes were milked by machine and were fed ad libitum twice daily, at 7:00 and 16:00 hour on an alfalfa hay and concentrated feed in pellets, designed to meet their maintenance and lactation requirements. Water was freely available. Milk samples were collected and fat content was determined according to Gerber method. Milk energy content was estimated in $\mathrm{Mj}$ of Net Energy according to the following equation [17]: $E=[91.17 \mathrm{M}(4.97+f)] 0.00418$, where: $E=$ milk energy $(\mathrm{Mj}), \mathrm{M}=$ milk yield $(\mathrm{kg} /$ day $)$, $f=$ milk fat content $(\%)$.

Once per week samples of subcutaneous adipose tissue from tail region were taken, by biopsy. A day before sampling ewes fasted (24 hours) with free access in water, and in the day of sampling ewes were anaesthetized with the use of Zoletin 50 in $15-20 \mathrm{mg} / \mathrm{kg}$ BW. One sample $(4-5 \mathrm{~g})$ from adipose tissue was immediately frozen at $-20^{\circ} \mathrm{C}$ for the determination of enzyme activity and lipid extraction. The second sample $(0.5-1 \mathrm{~g})$ was placed in Krebs-Ringer bicarbonate buffer $\left(\mathrm{pH}=7.4,37^{\circ} \mathrm{C}\right)$ for the measurement of adipocytes size and number, where as the third sample $(\sim 2.5-3.0 \mathrm{~g})$ was immediately frozen in liquid $\mathrm{N}_{2}$ and stored at $-80^{\circ} \mathrm{C}$ for further RNA extraction.

2.2. Biochemical Parameters. The diameter of 200 fat cells from each sample was measured as described by Rodbell [18]. The mean fat cell volume $(V)$ of the 200 cells and mean adipocytes number/g adipose tissue were calculated from the mean diameter $(d)$ and the standard deviation $(s)$. The chemical fat content of adipose tissues was determined as described by Folch et al. [19].

For enzyme assay the method described by Rogdakis [20] was used. Enzyme activity was expressed as units per fat cell.

2.3. RNA Isolation and Reverse Transcription. Samples from tail subcutaneous adipose tissue were taken by biopsy. Total RNA from ovine adipose tissue was extracted using "Rneasy Lipid Tissue Kit” (Qiagen Cat no. 74804). For first-strand cDNA synthesis a two-step RT-PCR procedure was followed using $1 \mathrm{ug}$ of the eluted total RNA, which was pre-treated with DNase I and Omniscript Reverse transcriptase (Qiagen) according to manufacturer's recommendations.

2.4. Semiquantitative RT-PCR Analysis. Total RNA from sheep adipose tissue was isolated as described above and used as template for a semi-quantitative RT-PCR analysis. For analysis, Ambion's QuantumRNA 18S Internal Standards Kit was employed, resulting in a 324 bp product. For 6PGD gene amplification the specific primers FP7: 5'-GGCCTACCACCTGATGAAGGACG-3' and RP8: 5'-GCCAAATTCAGTTGCTGCCTGTC-3' were used resulting in a $378 \mathrm{bp}$ product. Multiplex PCR conditions were: $94^{\circ} \mathrm{C}$ for 3 minutes followed by 30 cycles each of $94^{\circ} \mathrm{C}$ for 30 seconds, $60^{\circ} \mathrm{C}$ for 30 seconds, $72^{\circ} \mathrm{C}$ for 30 seconds, with a final extension at $72^{\circ} \mathrm{C}$ for 2 minutes (Taq polymerase, New England Biolabs). The relative transcript amount was determined using the Scion Image software v. 4.0.3.2 (http://www.scioncorp.com/). Each sample was measured 4 times.

2.5. Statistical Analysis. Least Squares Procedures were employed in statistical analysis [21]. Fixed effects models were used to describe each individual observation concerning number and size of fat cells, enzymatic activity and transcriptional level of 6PGD that were affected by milk yield.

\section{Results}

Table 1 shows the average daily net milk energy ( $\mathrm{Mj})$, fat content (\%), and milk production $(\mathrm{kg})$. Group A possessed higher milk production $(2.083 \pm 0.108 \mathrm{~kg})$ and higher net milk energy $(8.545 \pm 0.454 \mathrm{Mj}, P \leq .001)$ than Group $\mathrm{B}(0.715 \pm 0.073 \mathrm{~kg}$ and $3.012 \pm 0.289 \mathrm{Mj}$, respectively). Concerning the size of the observed adipocytes, the average diameter of adipocytes of all ewes was $74.03 \pm 3.14 \mu \mathrm{m}$. However, ewes of group A possessed statistically $(P \leq .01)$ smaller adipocytes than group B $(64.38 \pm 4.49 \mu \mathrm{m}$ versus $83.67 \pm 2.94 \mu \mathrm{m}$, resp.).

An almost two fold greater number $(P \leq .01)$ of adipocytes per $g$ of adipose tissue, was observed in ewes of group A in contrast to that of group B. The average number of adipocytes of tail adipose tissue of group A ewes was $4.58 \pm 0.51 * 10^{6} / \mathrm{g}$ adipose tissue while group B possessed $2.20 \pm 0.34 * 10^{6}$ adipocytes/g adipose tissue. 
TABLE 1: Average milk yield (kg), milk fat content (\%) and net milk energy (Mj) of experimental ewes.

\begin{tabular}{lccc}
\hline Group & $\begin{array}{c}\text { Milk production } \\
(\mathrm{kg})\end{array}$ & $\begin{array}{c}\text { Fat content } \\
(\%)\end{array}$ & $\begin{array}{c}\text { Milk Energy } \\
(\mathrm{Mj})\end{array}$ \\
\hline $\mathrm{A}(n=6)$ & $2.083^{\mathrm{a} * * *} \pm 0.108$ & $5.867 \pm 0.431$ & $8.545^{\mathrm{a} * * *} \pm 0.454$ \\
$\mathrm{~B}(n=14)$ & $0.715^{\mathrm{b}} \pm 0.073$ & $6.054 \pm 0.176$ & $3.012^{\mathrm{b}} \pm 0.289$ \\
\hline
\end{tabular}

Means with different superscript letters differ significantly $\left({ }^{* * *} P \leq .001\right.$.)
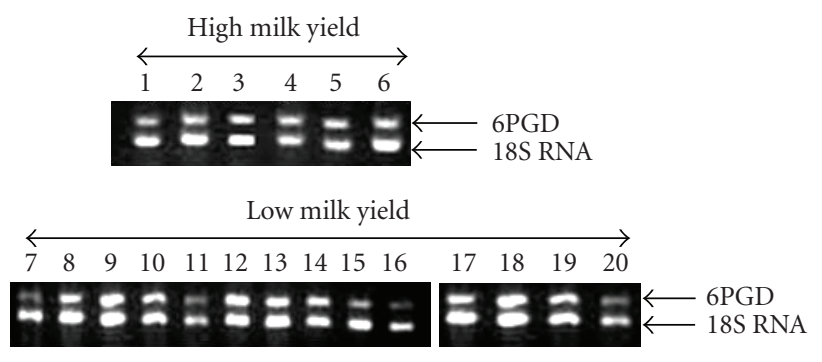

FIGURE 1: Expression analysis of 6PGD gene in tail adipose tissue of high and low milk yield ewes. All samples were normalized to $18 \mathrm{~S}$ RNA gene. $10 \mu \mathrm{L}$ of each sample were loaded in the agarose gel for electrophoresis. As the experimental conditions were the same for all the samples, the observed differences in the low milk yield group may be due to differences concerns the sample itself.

The determined average enzymatic activity was significantly $(P \leq .05)$ greater in ewes of group $\mathrm{B}$ than that observed in group A $(364.80 \pm 49.73 \mathrm{nmol} \mathrm{NADPH} *$ $\min ^{-1} / 10^{6}$ adipocytes and $76.80 \pm 13.50 \mathrm{nmol} \mathrm{NADPH}$ $* \min ^{-1} / 10^{6}$ adipocytes, resp.). Concerning 6PGD gene expression in the two groups during lactation (Figure 1) an increased transcript expression was observed in ewes of group B compared with the ewes of group A $(0.693 \pm 0.060$ versus $0.595 \pm 0.085$, resp.). However, this difference was not statistically significant. Moreover, 6PGD expression did not follow the acute changes of enzymatic activity and milk energy level concerning the two groups (Figure 2).

\section{Discussion}

During lactation, udder is the tissue with the highest metabolic activity. In this study, the metabolic adaptations of tail adipose tissue of Chios ewes during milk production were of particular interest.

Factors such as genotype, feed availability, body condition, number and weight of lambs at birth, environmental stimuli and their interaction may influence the daily milk production. According to Chilliard et al. [22], the mobilization of body fat depends on the initial body weight, as has been observed in sheep and dairy cows. As no differentiation of the body weight was observed during the study, the comparability of parameters between the examined groups was ensured.

Regarding the number of adipocytes observed in this study, ewes of group A had approximately a two-fold increase of the observed number of fat cells/g adipose tissue in respect to that of group B ewes. The observed range of values

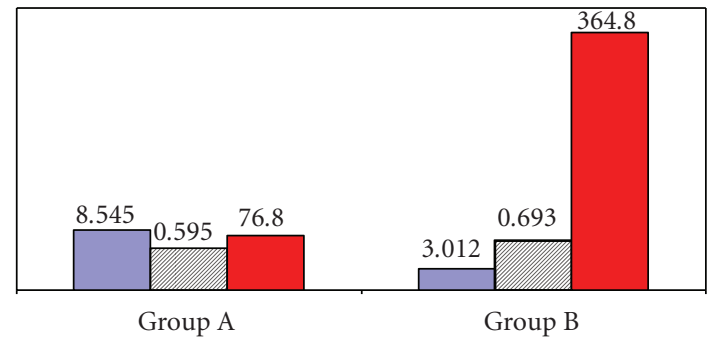

$\square$ Milk energy
$\square$ 6PGD expression
$\square$ 6PGD activity

FIgURE 2: Correlation among enzymatic activity (nmol $\mathrm{NADPH} / 10^{6}$ adipocytes), gene expression of $6 \mathrm{PGD}$ and milk energy $(\mathrm{Mj})$ of lactating ewes.

regarding the number of fat cells observed in this experiment was significantly higher than the values recorded by previous researchers $[11,23,24]$. The difference is probably due to different productivity breeds of ewes (meat type breeds) and to the fact that the lambs in the experiments of Vernon et al. [23] and Travers et al. [24] have not been weaned.

Comparing the size of fat cells in tail adipose tissue of the ewes it was observed that the fat cells were on average significantly smaller in ewes with high milk production than in ewes with low milk production. This result was expected since the highly productive ewes have greater energy requirements than that of ewes with low milk production and, thus, the pathway of lipolysis was more intensive in tail adipose tissue in order to cover the energy requirements of udder [25]. It is obvious that the catabolic activity of tail adipose tissue of ewes of group A in this study was higher as the quantity and the milk energy were increased. This observation is consistent with observations of Vernon et al. [23].

Diversification of lipogenic dehydrogenases activity such as 6PGD between animals with different milk productivity indicates the dependence of lipogenesis of ewes during lactation on the total energy content of the milk. In our study, the activity of 6PGD is reduced as the energy of the produced milk is increased (Figure 2). This observation was expected, as the ewes in group B due to the low milk production had lower energy requirements in order to meet the energy needs of the udder. In group A, a significantly less 6PGD activity was observed (Figure 2). In this case, the metabolic pathway of liposynthesis is limited, reducing thus the activity of lipogenic enzymes in order energy to be utilized for the maintenance of homeostasis of the body.

As shown in Figure 2, 6PGD activity in tail adipose tissue is reduced with the increase of milk energy. However, the difference in the values of 6PGD gene expression between the two groups was not statistically significant, although a decrease of expression was observed with the increase of milk production. The fact that the number of 6PGD gene transcripts between the two groups did not change significantly indicates that the control of 6PGD in adipose tissue during lactation may take place in translation and/or 
post-translation level, as previous authors have noted for important lipogenic genes during lactation, such as ACC $[24,26]$. Moreover, in the low yield ewes group there seems to be an increasing rate of transcription of the 6PGD gene. This, may be due to more possible involvement of other mechanisms than the regulation of translation for example, the presence of a SNP, which might facilitate the rate of transcription (group B) or affect the post transcriptional events (group A).

To sum up, the level of milk production significantly affects the metabolic role of tail subcutaneous adipose tissue. In ewes with high milk production, the pathway of lipogenesis is limited by reducing the size of fat cells and reducing the activity of 6PGD. In ewes with low milk production this restriction is less intense, as these animals have lower energy requirements compared to ewes with high milk production. The changes in the number of 6PGD gene transcripts in tail adipose tissue are not analogous either to the changes of 6PGD activity or to the level of milk production. 6PGD expression in the tail adipose tissue during dairy production is likely to be controlled through posttranscription and/or post-translation mechanisms. However, further research should be conducted in order to detect any potential relationship between gene expression, 6PGD activity and milk yield in sheep.

\section{Abbreviations}

$\begin{array}{ll}\text { aa: } & \text { Amino acids } \\ \text { bp: } & \text { Base pair } \\ \text { ACC: } & \text { Acetyl coenzyme A carboxylase } \\ \text { BW: } & \text { Body Weight } \\ \text { cDNA: } & \text { DNA complementary to RNA } \\ \text { dNTPs: } & \text { Deoxyribonucleotides triphosphate } \\ \text { 6PGD: } & \text { 6-phosphogluconate dehydrogenase } \\ \text { kDa: } & \text { Kilodalton } \\ \text { MDH: } & \text { Malate dehydrogenase } \\ \text { NADP: } & \text { Nicotinamide adenine dinucleotide phosphate } \\ \text { NADPH: } & \text { Reduced nicotinamide adenine dinucleotide } \\ & \text { phosphate } \\ \text { PCR: } & \text { Polymerase chain reaction } \\ \text { RT: } & \text { Reverse transcription. }\end{array}$

\section{Acknowledgment}

The experiment was approved by the Bioethical Committee of the Agricultural University of Athens.

\section{References}

[1] C. Phillips, S. Gover, and M. J. Adams, "Structure of 6phosphogluconate dehydrogenase refined at $2 \AA$ resolution," Acta Crystallographica Section D, vol. 51, part 3, pp. 290-304, 1995.

[2] K. E. Belk, J. W. Savell, S. K. Davis, J. F. Taylor, J. E. Womack, and S. B. Smith, "Tissue-specific activity of pentose cycle oxidative enzymes during feeder lamb development," Journal of Animal Science, vol. 71, no. 7, pp. 1796-1804, 1993.
[3] S. K. W. Tsui, J. Y. W. Chan, M. M. Y. Waye, K. P. Fung, and C. Y. Lee, "Identification of a cDNA encoding 6phosphogluconate dehydrogenase from a human heart cDNA library," Biochemical Genetics, vol. 34, no. 9-10, pp. 367-373, 1996.

[4] J. Mitoma, S. Furuya, M. Shimizu, et al., "Mouse 3phosphoglycerate dehydrogenase gene: genomic organization, chromosomal localization, and promoter analysis," Gene, vol. 334, no. 1-2, pp. 15-22, 2004.

[5] J. Yamada, T. Kuramoto, and T. Serikawa, "A rat genetic linkage map and comparative maps for mouse or human homologous rat genes," Mammalian Genome, vol. 5, no. 2, pp. 63-83, 1994.

[6] I. Harbitz, B. Chowdhary, R. Chowdhary, et al., "Isolation, characterization and chromosomal assignment of a partial cDNA for porcine 6-phosphogluconate dehydrogenase," Hereditas, vol. 112, no. 1, pp. 83-88, 1990.

[7] M. A. Rosemeyer, "The biochemistry of glucose-6-phosphate dehydrogenase, 6-phosphogluconate dehydrogenase and glutathione reductase," Cell Biochemistry and Function, vol. 5, no. 2, pp. 79-95, 1987.

[8] M. J. Adams, S. Gover, R. Leaback, C. Phillips, and D. O. Somers, "The structure of 6-phosphogluconate dehydrogenase refined at $2.5 \AA$ resolution," Acta Crystallographica Section $B$, vol. 47, part 5, pp. 817-820, 1991.

[9] A. Carne and J. E. Walker, "Amino acid sequence of ovine 6phosphogluconate dehydrogenase," The Journal of Biological Chemistry, vol. 258, no. 21, pp. 12895-12906, 1983.

[10] D. O. Somers, S. M. Medd, J. E. Walker, and M. J. Adams, "Sheep 6-phosphogluconate dehydrogenase. Revised protein sequence based upon the sequences of cDNA clones obtained with the polymerase chain reaction," Biochemical Journal, vol. 288, part 3, pp. 1061-1067, 1992.

[11] S. B. Smith and R. L. Prior, "Comparisons of lipogenesis and glucose metabolism between ovine and bovine adipose tissues," Journal of Nutrition, vol. 116, no. 7, pp. 1279-1286, 1986.

[12] J. M. Thompson and R. M. Butterfield, "Changes in body composition relative to weight and maturity of Australian Dorset Horn rams and wethers. 4. Adipocyte number and volume in dissected fat partitions," Animal Production, vol. 46, pp. 387-393, 1988.

[13] E. Panopoulou, S. Deligeorgis, T. Papadimitriou, and E. Rogdakis, "Carcass composition, size of fat cells and NADP generating dehydrogenases activity in adipose tissue of the fattailed Chios and thin-taled Karagouniko sheep breed," Journal of Animal Breeding and Genetics, vol. 106, pp. 51-58, 1989.

[14] A. Ayala, I. Fabregat, and A. Machado, "The role of NADPH in the regulation of glucose-6-phosphate and 6phosphogluconate dehydrogenases in rat adipose tissue," Molecular and Cellular Biochemistry, vol. 105, no. 1, pp. 1-5, 1991.

[15] E. Rogdakis, M. Charismiadou, S. Orphanos, E. Panopoulou, and I. Bizelis, "Cellularity and enzymatic activity of adipose tissue in the Karagouniko dairy breed of sheep from birth to maturity," Journal of Animal Breeding and Genetics, vol. 114, no. 5, pp. 385-396, 1997.

[16] M. Rippa, P. P. Giovannini, M. P. Barrett, F. Dallocchio, and S. Hanau, "6-phosphogluconate dehydrogenase: the mechanism of action investigated by a comparison of the enzyme from different species," Biochimica et Biophysica Acta, vol. 1429, no. 1, pp. 83-92, 1998.

[17] A. P. Mavrogenis and C. Papachristoforou, "Estimation of the energy value of milk and prediction of fat-corrected milk yield 
in sheep and goats," Small Ruminant Research, vol. 1, no. 3, pp. 229-236, 1988.

[18] M. Rodbell, "Localization of lipoprotein lipase in fat cells of rat adipose tissue," The Journal of Biological Chemistry, vol. 239, pp. 753-755, 1964.

[19] J. Folch, M. Lees, and G. Sloane-Stanley, "A simple method for the isolation and purification of total lipids from animal tissues," The Journal of Biological Chemistry, vol. 226, pp. 497509, 1957.

[20] E. Rogdakis, "Untersuchungen ueber die Aktivitaet NADPHliefernder Enzyme im Fettgewebe des Schweines. I. Mitt: biopsietechnik und enzymteste sowie enzymatische Unterschiede zwischen verschiedenen anatomischen Stellen des Fettgewebes," Zeitschrift für Tierphysiologie, Tierernährung und Futtermittelkunde, vol. 33, pp. 329-338, 1974.

[21] SAS/STAT User's Guide, Version 6. SAS Inst., Inc. Cary, NC, USA, 2006.

[22] Y. Chilliard, A. Ferlay, Y. Faulconnier, M. Bonnet, J. Rouel, and F. Bocquier, "Adipose tissue metabolism and its role in adaptations to undernutrition in ruminants," Proceedings of the Nutrition Society, vol. 59, no. 1, pp. 127-134, 2000.

[23] R. G. Vernon, A. Faulkner, E. Finley, H. Pollock, and E. Taylor, "Enzymes of glucose and fatty acid metabolism of liver, kidney, skeletal muscle, adipose tissue and mammary gland of lactating and non-lactating sheep," Journal of Animal Science, vol. 64, no. 5, pp. 1395-1411, 1987.

[24] M. T. Travers, R. G. Vernon, and M. C. Barber, "Repression of the acetyl-CoA carboxylase gene in ovine adipose tissue during lactation: the role of insulin responsiveness," Journal of Molecular Endocrinology, vol. 19, no. 2, pp. 99-107, 1997.

[25] J. P. McNamara and J. K. Hillers, "Regulation of bovine adipose tissue metabolism during lactation. 1. Lipid synthesis in response to increased milk production and decreased energy intake," Journal of Dairy Science, vol. 69, no. 12, pp. 3032-3041, 1986.

[26] R. G. Vernon, M. C. Barber, and E. Finley, "Modulation of the activity of acetyl-CoA carboxylase and other lipogenic enzymes by growth hormone, insulin and dexamethasone in sheep adipose tissue and relationship to adaptations to lactation," Biochemical Journal, vol. 274, no. 2, pp. 543-548, 1991. 

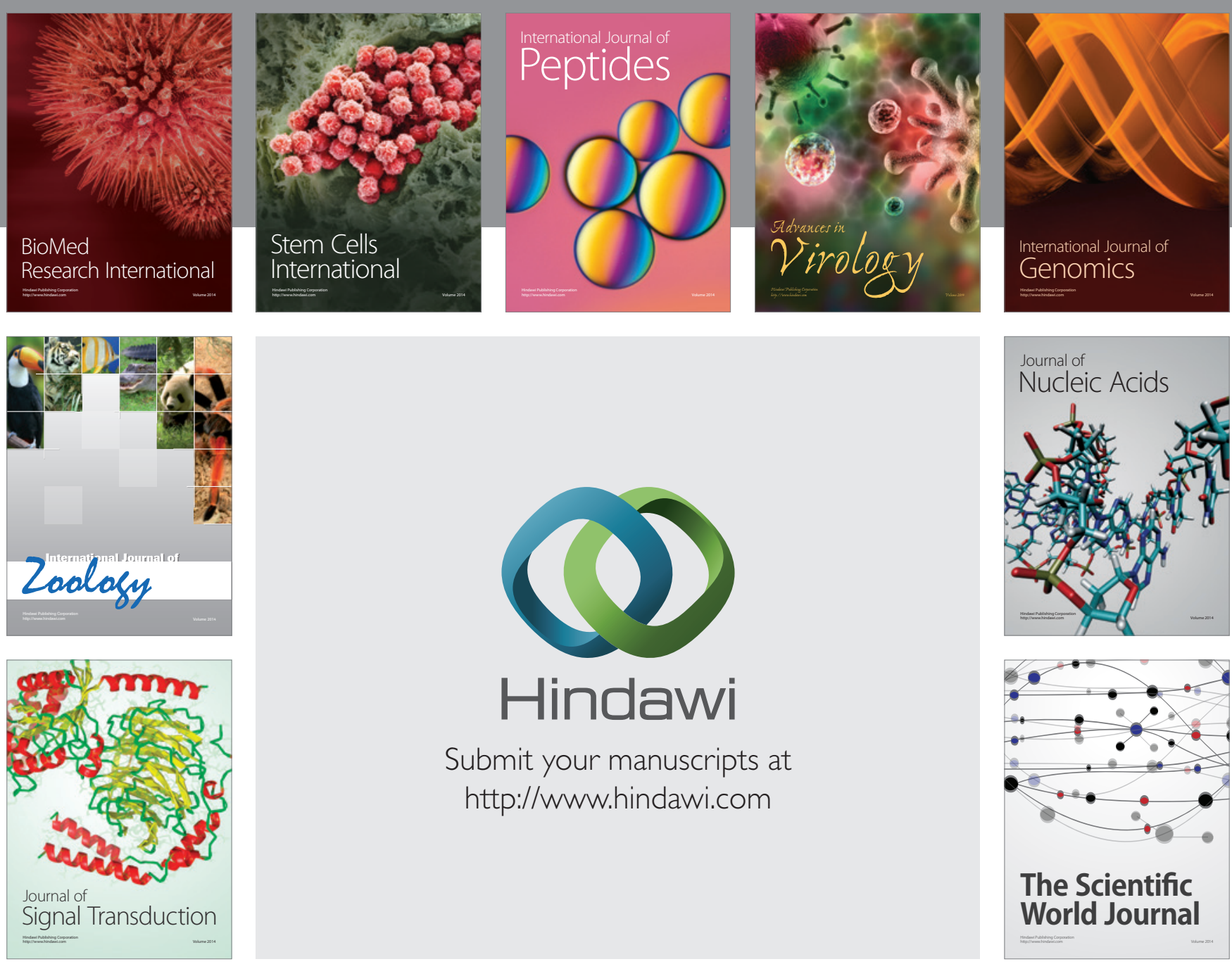

Submit your manuscripts at

http://www.hindawi.com
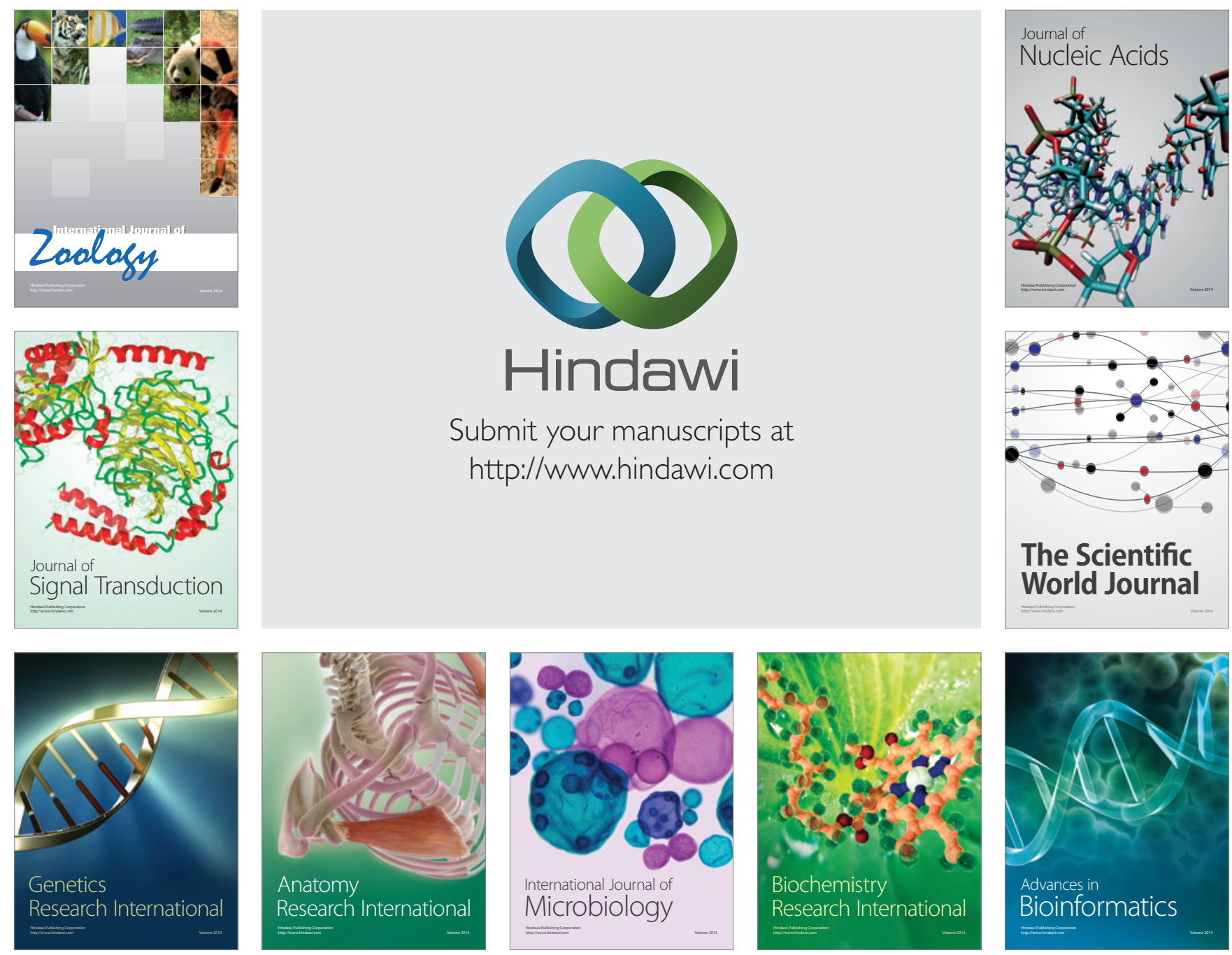

The Scientific World Journal
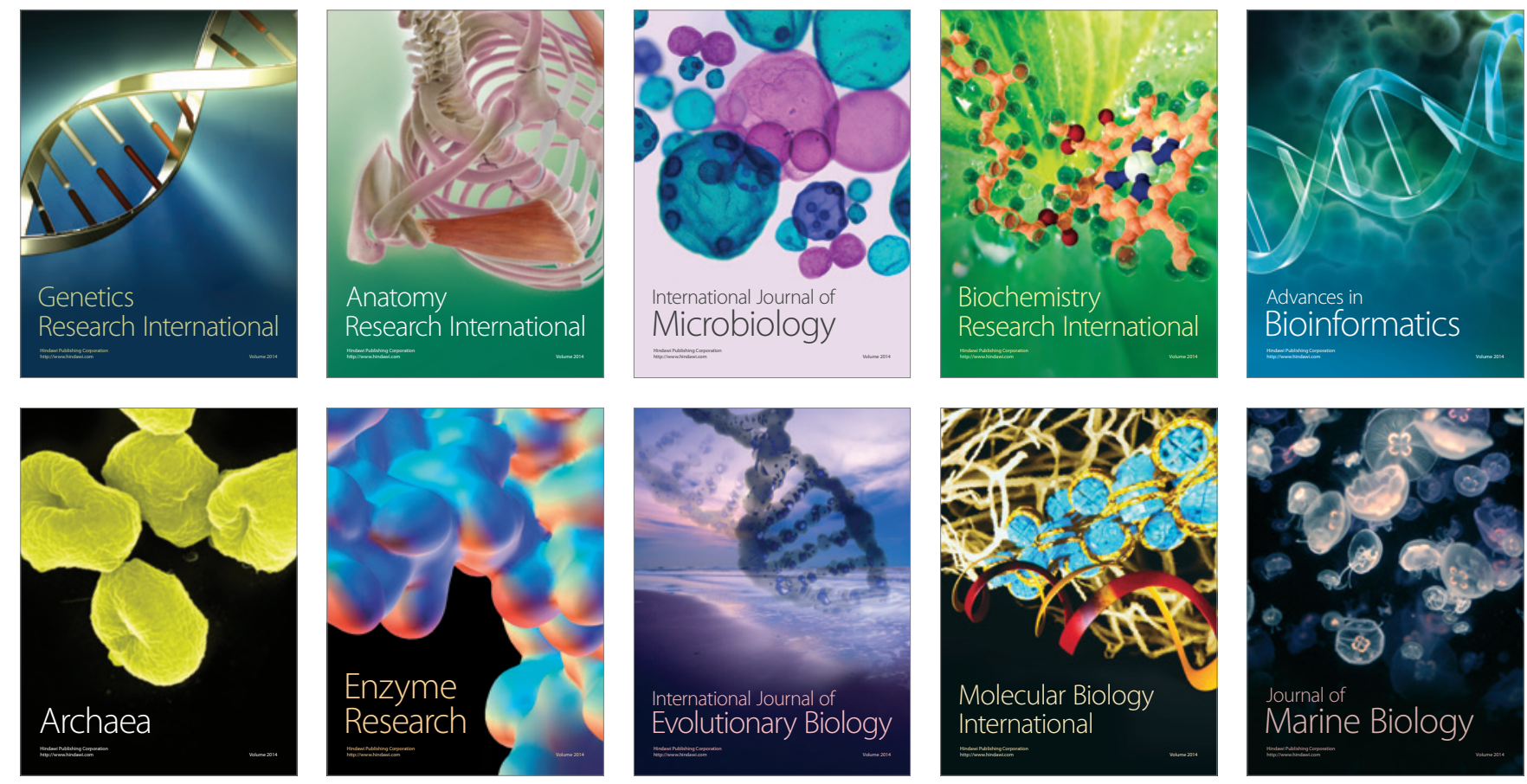